\title{
The aesthetic evaluation of forest landscape in four urban forest parks: A case study of Nanjing hilly areas, China
}

\section{Yang Yang ( $\sim$ ocean1999@yeah.net)}

Nanjing Forestry University https://orcid.org/0000-0002-7204-2280

Xiaolan Tang

Nanjing Forestry University

\section{Research Article}

Keywords: Landscape aesthetic evaluation, forest landscape, urban forest park, SD method, PCA method, suggestion

Posted Date: May 3rd, 2021

DOI: https://doi.org/10.21203/rs.3.rs-286000/v1

License: (c) (i) This work is licensed under a Creative Commons Attribution 4.0 International License. Read Full License 


\section{Abstract}

In recent years, the construction of urban forest parks has run into the fast lane in China. As an indispensable natural landscape resource for urban forest parks, forest landscape has been paid increasing attentions by the public, in contrast, less effort has been made in the field of aesthetic evaluation of forest landscape. Based on the theories of landscape esthetics and psychology, this paper aims to present methods for the aesthetic evaluation, and understand citizen's aesthetic perceptions of forest landscape using Semantic Differential (SD) and Principal Component Analysis (PCA) methods. Moreover, further suggestions will be put forward for a better development of the forest landscape, thereby giving full play to their landscape and recreation functions. As per the findings of this paper, the vegetation element diversity (PC 1 ), the magnificent feel (PC 2 ), the nature-pastoral feel (PC 3 ) and the sense of space (PC 4 ) present the critical comprehensive indexes affecting the aesthetic values of the forest landscape. The relationship between the comprehensive indexes and the landscape aesthetic value is revealed by multiple regression analyses. PC 3 and PC 4 are found to be less influencing on aesthetic values than PC 1 and PC 2 . At last, three suggestions for the construction and protection of forest landscape are put forward. The results of this study will contribute to the preservation of the forest landscape aesthetic, and the integration of these conclusions into the sustainable development strategies of urban forest parks.

\section{Introduction}

Forest landscape not only presents the most vital landscape resource, but also plays an important role in allowing citizens to get closer to nature, and restore their bodies and mind in forest parks (Garman, 2004; Silva et al., 2015; Liu, et al., 2019). In many Chinese cities, forest park tourism is becoming the most dynamic point of economic growth (Malik et al., 2016; Kisi, 2019). There are 3,505 forest parks in China, receiving about 962 million tourists every year. In 2018, forest park tourism made a contribution of \$12.67 billion in direct revenue and $\$ 122.89$ billion in indirect revenue. While appreciating the beautiful scenery of forest landscape, people can also enjoy diversified activities, such as parties, sightseeing, recreation, scientific research and education. In conclusion, forest landscape is considered as a perfect place to fully enjoy the pleasure of nature in forest parks (Hessburg et al., 2013; Silva et al., 2015).

Since then, Nanjing, as the capital city of Jiangsu province in China, has developed quickly区accelerated urban construction, significant increase of infrastructure and traffic projects, and rapid development of tourism. Since 1982, 13 forest parks, including five national forest parks, have been built. However, field investigations revealed that multiple problems still exist regarding the forest landscape of urban forest parks, that is, some forest landscapes still at young or mid-maturation stages, low species diversity, poor growth status, and over low density. These shortcomings have been identified to have impact on the aesthetic value of forest landscape. In that case, it is necessary to evaluate the forest landscape aesthetic, thereby providing a scientific basis for forests planning and management to cater to the public's sightseeing needs (Rizio and Gios, 2014; Zhang et al., 2015; Takayama et al., 2017). 
The aesthetic evaluation presents an important topic in researching and stablishing landscape quality (Saleh, 2001; Petrova et al., 2015 ; Ha and Yang, 2019). According to Daniel (Daniel, 2001), landscape evaluation is defined as a value judgment involving the comprehensive reflection of observers to objects. Many researches have carried out quantitative evaluations on different types of landscape quality (Micallef et al., 2011; Yazici, 2018; Romero et al., 2019), including Scenic Beauty Estimation Method (SBE) (Yang, 2014; Qi et al., 2017), Analytic Hierarchy Process Method (AHP) (Liu et al., 2009; Zhang and Yang, 2016), Semantic Differential Method (SD) (Munoz-Pedreros and Larrain, 2002; Cervinka et al., 2014) and Physiological Psychology Index Testing Method (PPIT) (Song et al., 2014; Ikei et al., 2017). Unfortunately, less work is done in the field of quantitative aesthetic evaluation of forest landscape.

This paper proposed an aesthetic evaluation for forest landscape using Semantic Differential method (SD) and Principal Component Analysis (PCA) method. SD, proposed by Osgood et al. (Tarakci-Eren and Duzenli, 2017), refers to a kind of psychological determination method, and the most powerful quantitative method to analyze affective meanings in many different assessment fields, such as solar power plants (Torres-Sibille et al., 2009), waterfalls, waterfalls (Kurdoglu and Kurdoglu, 2016), and people's feeling in the forest (Song et al., 2019). While, PCA, put forward by Pearson, is utilized for feature extraction of information, and dimensionality reduction of data (Schirpke et al., 2013; Jeon et al., 2014). The greatest advantage of PCA for multiple indicators lies in the fact that it is available to eliminate the relevant influences among all indicators, and improve the description of the interaction among diverse factors more objectively. PCA has been applied to the evaluation of waterfront landscape (Kim and Kang, 2009), park landscape (Kotlarz et al., 2016; Wan and Fan, 2018) and various urban landscape (Wang et al., 2011). These two proposed methods improve the applicability and quality of landscape aesthetic evaluation, and has been utilized in four urban forest parks in Nanjing hilly areas. The main objectives of this study are as follows: (1) To propose the multi-criteria system of aesthetic evaluation for forest landscape based on the theories of landscape esthetics and psychology; (2) To evaluate the aesthetic values of forest landscape in four urban forest parks with the methods of SD and PCA, and obtain the most critical comprehensive indexes that affect the aesthetic value of forest landscape; (3) To provide suggestions and guidance for long-term development planning and management of forest landscape in the study area.

\section{Materials And Methods}

\subsection{Study area}

Located in the north subtropical monsoon humid areas, Nanjing is one of the first outstanding tourist cities in China. The average annual precipitation is $1106.5 \mathrm{~mm}$, and the annual average temperature is $15.4^{\circ} \mathrm{C}$, besides, the annual extreme temperature is $39.7^{\circ} \mathrm{C}(\mathrm{max})$ and $13.1^{\circ} \mathrm{C}(\mathrm{min})$, respectively. Four urban forest parks are selected in this study as the research objects, i.e., Niushou mountain forest park in the south of Nanjing, Zijin Mountain Forest Park in the middle of Nanjing, Qixia Mountain Forest Park in the east of Nanjing and Laoshan Forest Park in the west of Nanjing (Figure 1). These four urban forest 
parks surround the urban built-up areas, thus forming the important natural tourism and leisure areas in Nanjing.

(1) Niushou Mountain Forest Park is a famous Buddhist mountain in Nanjing, which was selected as one of Forty-eight Scenery of Nanjing (in the Ming Dynasty (1368-1644 AD).

(2) Zijin Mountain Forest Park is one of the first national 5A-level scenic spots. The forest area of Zijin Mountain accounts for $15.6 \%$ of the total forest area of Nanjing, moreover, multitude of ancient trees are found growing there.

(3) Qixia Mountain Forest Park is one of the four major scenic spots of Maple trees in China, which is selected as one of Forty-eight Scenery of Nanjing (in the Ming Dynasty (1368-1644 AD). A variety of redleaf trees grow there, such as Liquidambar formosana, Acer buergerianum, Acer palmatum, etc.

(4) Laoshan Forest Park is the largest national forest park in Jiangsu Province. There are numerous ancient, large and infrequent trees, such as Ginkgo biloba, Zelkova serrata, Celtis sinensis, etc.

\subsection{Research Procedure}

The aesthetic evaluation of forest landscape made in this paper consists of following main parts. (1) SD method is applied to the aesthetic evaluation of 64 forest landscapes in four urban forest parks. (2) Determine the comprehensive indexes which present the key factors affecting the forest landscape by PCA method, and multiple regression analysis. The comprehensive index can clearly and objectively reflect landscape characteristics, which is favorable for controlling visual and psychological attributes of aesthetic values of the forest landscape. (3) All forest landscapes in this study are divided into four individual types based on cluster analysis. (4) Moreover, analyses of comprehensive indexes and the differences of these forest landscapes further confirm, and are in agreement with the resultant circumstance results of the above research projects. (5) The construction of aesthetic evaluation model for the forest landscape facilitates the description of how comprehensive indexes exercise their influence on landscape aesthetic and the influence level. (6) Finally, suggestions on the forest landscape construction and protection are presented for long-term development planning and management in urban forest parks, thereby bringing forests' landscape and recreation functions into full play for citizens.

2.3 Multi-criteria concerning aesthetic evaluation for forest landscape

In general, about 15-20 criteria are appropriate to be used for making determination in SD method (Santosa et al., 2018; Jiang et al., 2019). As indicated in Table 1, the aesthetic evaluation criteria including the principles of stability, independence, systematicness, and comprehensiveness were built. Among all the evaluation criteria, the first eight are related to visual sense, and the last seven are in connection with psychological perception. The evaluation criterion given in Table 1 was derived from the proper understanding of each factor's intrinsic properties and its impact on the development of forest landscape, which is in accordance with the actual situation in the study area, and in combination with the literature, expert opinions, relevant regulations and standards of forest landscape. In this study, each evaluation 
criterion is divided into 5-point scale. The higher the score of an evaluation criterion in one forest landscape, the closer the evaluation criterion is to the right adjective meaning (Table 1).

Table 1. Criteria of aesthetic evaluation for forest landscape

\begin{tabular}{|c|c|c|c|}
\hline Criteria category & Criterion & Negative Boundary & Positive Boundary \\
\hline (0 point) & (5 point) & & \\
\hline Visual sense & $\begin{array}{l}\text { Vegetation element } \\
\text { richness (VER) }\end{array}$ & $\begin{array}{l}\text { Forest components are } \\
\text { single }\end{array}$ & $\begin{array}{l}\text { Forest } \\
\text { components are } \\
\text { rich }\end{array}$ \\
\hline $\begin{array}{l}\text { Canopy } \\
\text { characteristic (CC) }\end{array}$ & $\begin{array}{l}\text { Canopy characteristics are } \\
\text { monotonous }\end{array}$ & $\begin{array}{l}\text { Canopy characteristics } \\
\text { are varied }\end{array}$ & \\
\hline $\begin{array}{l}\text { Vegetation diversity } \\
\text { (VD) }\end{array}$ & Vegetation type is single & Vegetation type is rich & \\
\hline $\begin{array}{l}\text { Vegetation } \\
\text { prominence (VP) }\end{array}$ & $\begin{array}{l}\text { Visual occupancy of } \\
\text { vegetation is low }\end{array}$ & $\begin{array}{l}\text { Visual occupancy of } \\
\text { vegetation is high }\end{array}$ & \\
\hline Color richness (CR) & Color is single & Color is rich & \\
\hline Color luster (CL) & Color luster is dim & Color luster is bright & \\
\hline Sense of space (SS) & Space is closed & Space is open & \\
\hline $\begin{array}{l}\text { Age of main trees } \\
\text { (AMT) }\end{array}$ & $\begin{array}{l}\text { The main trees are young } \\
\text { ones }\end{array}$ & $\begin{array}{l}\text { The main trees are the } \\
\text { older ones }\end{array}$ & \\
\hline $\begin{array}{l}\text { Psychological } \\
\text { perception }\end{array}$ & Wildness (WI) & There is no wildness & There is wildness \\
\hline Harmony (HA) & Inharmonious & Harmonious & \\
\hline Localism (LO) & Urbanism & Local flavor & \\
\hline Naturalness (NA) & Artificial & Natural & \\
\hline $\begin{array}{l}\text { Sense of simplicity } \\
\text { (SS) }\end{array}$ & Delicate & Simple & \\
\hline $\begin{array}{l}\text { Sense of beauty } \\
\text { (SB) }\end{array}$ & Ugly & Beautiful & \\
\hline $\begin{array}{l}\text { Sense of familiarity } \\
\text { (SF) }\end{array}$ & Unfamiliar & Familiar & \\
\hline $\begin{array}{l}\text { Scores of landscape } \\
\text { aesthetics }\end{array}$ & $\begin{array}{l}\text { Landscape aesthetic value } \\
\text { (LAV) }\end{array}$ & Low aesthetic value & $\begin{array}{l}\text { High aesthetic } \\
\text { value }\end{array}$ \\
\hline
\end{tabular}

VER, VP: Criteria referred to the research of rural areas in terms of landscape quality according to Ertan Düzgüneş (Ertan Düzgüneş et al. 2015). 
CC, VD, CR, CL: Criteria referred to the research of relationship between forest color characteristics and scenic beauty (Zhang et al. 2017).

SS, AMT: Criteria based on the research of visitors' preferences and evaluation of satisfaction with forest trails (Zhang et al. 2019).

WI, SB, SF: Criteria based on the Measures for the administration of national forest parks (2011) according to Chinese State Forestry Bureau.

HA: Criteria referred to the research of the aesthetic evaluation of coastal landscape according to Nam Hyeong Kim (Nam et al. 2009).

LO, NA, SS: Criteria referred to evaluation for landscape aesthetic value of the Natural World Heritage Site according to Shangchen $\mathrm{Ha}$ (Ha et al. 2019).

\subsection{Evaluators Characteristics}

Based on the research conclusions that there is no significant individual differences in many landscape evaluations (Lim et al., 2006; Park et al., 2011), 220 respondents participated in this study. These participants are all postgraduates in their mid-20s, and in the 1th or 2th grade of the Dept. of Forestry and Landscape Architecture in Nanjing Forestry University. It can be seen from Table 2 that the 220 invited respondents are nearly balanced in terms of gender. All the respondents have lived for at least one year in Nanjing, and are familiar with the local forest parks (Table 2). Thus, it is feasible for them to respond more aggressively in this evaluation experiment. Based on the 5-point scale, the score of 64 samples of forest landscape given by 220 respondents is shown in Figure 2.

Table 2. Basic demographics of 220 respondents 


\begin{tabular}{|c|c|c|c|c|c|c|c|c|}
\hline Category & Sub-category & & & & & & & \\
\hline Gender & Male & 120 & Female & 100 & & & & \\
\hline Education & $\begin{array}{l}\text { Postgraduate } \\
\text { students }\end{array}$ & & & & & & & \\
\hline Major & Forestry & 105 & $\begin{array}{l}\text { Landscape } \\
\text { architecture }\end{array}$ & 115 & & & & \\
\hline Hometown & North China & 18 & East China & 85 & $\begin{array}{l}\text { South } \\
\text { China }\end{array}$ & 45 & $\begin{array}{l}\text { Southwest } \\
\text { China }\end{array}$ & 32 \\
\hline $\begin{array}{l}\text { Northeast } \\
\text { China }\end{array}$ & 10 & $\begin{array}{l}\text { Central } \\
\text { China }\end{array}$ & 20 & $\begin{array}{l}\text { Northwest } \\
\text { China }\end{array}$ & 10 & & & \\
\hline $\begin{array}{l}\text { Annual } \\
\text { visiting } \\
\text { times to } \\
\text { forest park }\end{array}$ & $<5$ & 2 & $5-10$ & 30 & $11-20$ & 72 & & \\
\hline $21-50$ & 54 & $51-100$ & 24 & $>100$ & 38 & & & \\
\hline
\end{tabular}

\subsection{Photos for Evaluation}

The field survey was conducted as a pre-investigation of forest landscape in four urban forest parks. In addition, the latitude and longitude of each sample plot were recorded with a GPS instrument (Spectra Precision SP60); the illuminance was measured with a digital photometer (LX-102); the weather of day for the survey day, and the vegetation composition of the forest landscape were recorded as well. At the completion of the field investigation, the photograph of forest landscape was adopted as the evaluation media, which was obtained from a sample plot with an area of $10,000 \mathrm{~m}^{2}(100 \mathrm{~m} \star 100 \mathrm{~m})$. All photos are in accordance with the following principles to ensure the photographic consistency among variables, such as the slop and the sunshine environment. (1) All photos of samples were taken by one person in October 2019. (2) Forest landscapes were dominated by arbors, shrubs, and herbaceous plants. Slope of the sample plot was selected as a gentle slope $\left(6^{\circ}-15^{\circ}\right)$. (3) All photos were collected using a Sonny A7 with 40 million pixels under bright illumination between 10 a.m. and 3 p.m. The weather was fine, with 1-2 grade wind and excellent PM2.5 on the survey day. According to circumstances principles mentioned above, 64 photos were taken as the evaluation samples, of which, 16 photos were taken for each urban forest park (Appendix Figure 1).

\section{Results}

3.1 Analysis of the average scores of each evaluation criteria

The average scores of each evaluation criteria for the four forest parks are obtained, and that for the 64 forest landscapes are drawn in Figure 2. (1) The average scores of evaluation criteria in each of the four forest parks are quite different. The average scores of evaluation criteria in Niushou Mountain Forest Park are more inclined to 5 points, and the average scores of all criteria are almost higher than other three 
forest parks, owing to the vigorous construction of Niushou Mountain Forest Park by the Nanjing Municipal Government in recent years. Many forest landscape areas, such as: Chanlin Road, Fuding Temple and Fuding Palace, have shown fantastic forest landscape, and become popular tourist attractions. (2) The criteria of visual sense below 2.5 point are especially concentrated in $\mathrm{CC}$ and $\mathrm{CR}$, thereby explaining that the dissatisfaction of evaluators due to the defects of canopy characteristics, and insufficient color richness in the forest landscape. (3) The average scores of 13 aesthetic evaluation criteria for the 64 samples are moderately high (above 2.5 point), and only 2 criteria (CC, CR) are below the 2.5 point, indicating that the aesthetic quality of forest landscapes in the four urban forest parks is relatively good.

\subsection{Relationship between criteria and aesthetic values of forest landscapes}

Through one-way ANOVA analysis (Kuper, 2017), the correlations between VER, CC, VD, VP, CR, CL, AMT and LAV are found to be significant or very significant among the criteria of visual sense, however, $S S$ is not significant (as shown in Table 3). They are positively correlated with aesthetic values, and listed in the sequence from large to small as follows: $C C>V E R>V D>C R>V P>C L>A M T$. Among the criteria of psychological perception, HA, SS, SB and SF show significantly positive correlations with aesthetic values, however, other criteria are not significant. From large to small, they are listed as follows: $S B>H A>S F>S S$.

Table3. Correlation between criteria and aesthetic values of forest landscapes

\begin{tabular}{|c|c|c|c|c|c|c|c|c|c|}
\hline Criteria & LAV & VER & $\mathrm{CC}$ & VD & VP & $\mathrm{CR}$ & $\mathrm{CL}$ & SS & \\
\hline LAV & $P$ & 1 & $.610 \star \star$ & $.640^{\star \star *}$ & $.584^{\star \star}$ & $.447 \star \star$ & $.571^{\star \star}$ & $.344 \star \star$ & .064 \\
\hline Sig. & .000 & .000 & .000 & .000 & .000 & .000 & .005 & .615 & \\
\hline Criteria & AMT & WI & $\mathrm{HA}$ & LO & NA & SS & SB & SF & \\
\hline LAV & $P$ & $.305^{\star}$ & -.031 & $.587^{\star \star}$ & -.021 & -.177 & $.448^{\star \star}$ & $.733^{\star \star}$ & $.497^{\star \star}$ \\
\hline Sig. & .014 & .806 & .000 & .867 & .163 & .000 & .000 & .000 & \\
\hline
\end{tabular}

Note: ** denotes $p<0.01$, * denotes $p<0.05$;

The full names of abbreviations are shown in Table 1.

\subsection{Comprehensive index construction of forest landscape aesthetics}

Principal component analysis (PCA) method is adopted to detail the criteria with a high correlation degree into the comprehensive index, thereby simplifying the research parameters. According to PCA analysis, the Kaiser-Meyer-Olkin (KMO) is 0.779 (higher than 0.7), indicating that the variables are suitable for PCA. The first four factors are extracted to explain all the criteria based on the eigenvalue of first four factors which are greater than 1 . The accumulative contribution rates of the first four factors are $41.152 \%$, $57.626 \%, 71.220 \%$, and $80.982 \%$, respectively. As shown in Table 4, $\mathrm{PC}_{1}$ is strongly correlated with vegetation diversity (0.954), canopy characteristic (0.901), vegetation element richness (0.888), and color 
richness (0.816). $\mathrm{PC}_{1}$ reflects the vegetation element diversity of forest landscape. As such, $\mathrm{PC}_{1}$ is named as the vegetation element diversity. On the other hand, $\mathrm{PC}_{2}$ is in close relation to the sense of familiarity (0.779), age of main trees (0.722), sense of beauty $(0.721)$, sense of simplicity $(0.652)$, and harmony (0.645), all of which reflect the magnificent view degree of forest landscape. Hence, $\mathrm{PC}_{2}$ is named as the magnificent feel. While, $\mathrm{PC}_{3}$ is strongly correlated with wildness $(0.871)$, naturalness $(0.852)$, and localism (0.624), presenting the natural and pastoral sense of the forest landscape. Therefore, $\mathrm{PC}_{3}$ is defined as the nature-pastoral feel. $\mathrm{PC}_{4}$ is closely related to the sense of space $(-0.931)$, so that it is defined as the sense of space. For the calculation of the weight of each criteria in terms of its factor, the equations of four comprehensive indexes are as follows:

$\mathrm{PC}_{1}=0.425 \mathrm{VD}+0.402 \mathrm{CC}+0.396 \mathrm{VER}+0.364 \mathrm{CR}$

$\mathrm{PC}_{2}=0.549 \mathrm{SF}+0.509 \mathrm{AMT}+0.508 \mathrm{SB}+0.459 \mathrm{SS}+0.454 \mathrm{HA}$

$\mathrm{PC}_{3}=0.675 \mathrm{WI}+0.661 \mathrm{NA}+0.484 \mathrm{LO}$

$\mathrm{PC}_{4}=-1.023 \mathrm{SS}$

Table 4. Principal component analysis of multi-criteria 


\begin{tabular}{|c|c|c|c|c|c|}
\hline The extracted PCs & Criteria & Component & & & \\
\hline $1 \mathrm{st}$ & $2 s t$ & 3st & $4 s t$ & & \\
\hline $\mathrm{PC}_{1}$ & Vegetation diversity & .954 & .102 & .110 & -.017 \\
\hline Canopy characteristics & .901 & .131 & .089 & -.105 & \\
\hline Vegetation element richness & .888 & .267 & .172 & -.080 & \\
\hline Color richness & .816 & -.011 & -.309 & .140 & \\
\hline $\mathrm{PC}_{2}$ & Sense of familiarity & .025 & .779 & -.182 & -.104 \\
\hline Age of main trees & -.077 & .722 & .266 & .360 & \\
\hline Sense of beauty & .445 & .721 & -.252 & .153 & \\
\hline Sense of simplicity & .329 & .652 & .290 & -.014 & \\
\hline Harmony & .395 & .645 & -.335 & .018 & \\
\hline $\mathrm{PC}_{3}$ & Wildness & .198 & -.121 & .871 & -.007 \\
\hline Naturalness & -.058 & -.135 & .852 & .193 & \\
\hline Localism & -.119 & .276 & .624 & .289 & \\
\hline $\mathrm{PC}_{4}$ & Sense of space & .118 & -.011 & -.213 & -.931 \\
\hline Removed & Vegetation prominence & .549 & .390 & .205 & .524 \\
\hline Color luster & .230 & .097 & -.149 & -.054 & \\
\hline
\end{tabular}

Rotation Method: Varimax with Kaiser Normalization.

3.4 Classification of forest landscapes in four urban forest parks

Hierarchical clustering analysis (Mezosi et al., 2016; Campos and Oliveira, 2016) is utilized to determine the optimal number of clusters. And the scores of the comprehensive indexes and the aesthetic values of the 64 samples were employed as the variables and cases, respectively. The appendix Table 1 presents a cluster membership from 4- to 8- cluster. It can be seen from the agglomeration schedule, as a numerical summary of the cluster solution, the optimal number of clusters was considered to follow a 4- cluster solution.

The average values of comprehensive indexes in the same category of forest landscape are shown in Figure 3. The first category (C1) appears to show negative values in $\mathrm{PC}_{1}$, while presenting positive values in $\mathrm{PC}_{3}$ and $\mathrm{PC}_{4}$. The second category (C2) makes a positive impression on subjects about $\mathrm{PC}_{2}$ and $\mathrm{PC}_{4}$. The third category (C3) presents positive values except for $\mathrm{PC}_{4}$. And the fourth category (C4) shows the characteristics which are greatly negative in all the four PCs. 
The multiple comparisons of aesthetic value distribution in four clusters and comprehensive indexes are shown in Table 5. $\mathrm{PC}_{1}$ and $\mathrm{PC}_{2}$ increase linearly with the increase of aesthetic values from $\mathrm{C} 1$ to $\mathrm{C} 3$, and decrease linearly with the decrease of aesthetic values from $\mathrm{C} 3$ to $\mathrm{C} 4$. In addition, $\mathrm{PC}_{3}$ decreased between $\mathrm{C} 1$ and $\mathrm{C} 2$, as well as $\mathrm{C} 3$ and $\mathrm{C} 4$, but increased between $\mathrm{C} 2$ and $\mathrm{C} 3$. $\mathrm{PC}_{4}$ decreased after the first increase from $\mathrm{C} 1$ to $\mathrm{C} 2$. Multiple comparisons show that $\mathrm{PC}_{2}$ and $\mathrm{PC}_{3}$ are not significantly different among $\mathrm{C} 1, \mathrm{C} 2$, $\mathrm{C} 3$ and $\mathrm{C} 4$, and $\mathrm{PC}_{4}$ is not significantly different among $\mathrm{C} 1, \mathrm{C} 2, \mathrm{C} 3$, and $\mathrm{C} 4$. Besides $\mathrm{PC}_{3}$ and $\mathrm{PC}_{4}, \mathrm{PC}_{1}$ is significantly different between $\mathrm{C} 1, \mathrm{C} 2, \mathrm{C} 3$. Consequently, it is found that both $\mathrm{PC}_{3}$ and $\mathrm{PC}_{4}$ have less influence on aesthetic values than $\mathrm{PC}_{1}$ and $\mathrm{PC}_{2}$ do.

Table 5. Differences of aesthetic values and comprehensive indexes in four categories.

\begin{tabular}{|c|c|c|c|c|}
\hline Comprehensive indexes & C1 & $\mathrm{C} 2$ & C3 & $\mathrm{C4}$ \\
\hline LAV & $-0.72 \pm 0.25^{\star}$ & $0.72 \pm 0.24^{*}$ & $1.32 \pm 0.24^{\star}$ & $0.24 \pm 0.28$ \\
\hline $\mathrm{PC}_{1}$ & $-0.84 \pm 1.32^{\star}$ & $0.84 \pm 0.19 *$ & $2.28 \pm 0.19 *$ & $0.38 \pm 0.18$ \\
\hline $\mathrm{PC}_{2}$ & $-0.46 \pm 0.32$ & $0.46 \pm 0.35$ & $0.46 \pm 0.35$ & $-0.45 \pm 0.35$ \\
\hline $\mathrm{PC}_{3}$ & $0.49 \pm 0.33$ & $-0.54 \pm 0.36$ & $-0.18 \pm 0.36$ & $-0.86 \pm 0.35^{\star}$ \\
\hline $\mathrm{PC}_{4}$ & $-0.19 \pm 0.29$ & $0.19 \pm 0.30$ & $-.83 \pm 0.29 *$ & $-1.36 \pm 0.29 *$ \\
\hline
\end{tabular}

Note母* indicates significant differences at the 0.05 level.

3.5 Interactions between landscape aesthetic values and comprehensive indexes

Multiple regression analysis is adopted to determine the comprehensive index which is able to identify the aesthetic preference on the forest landscape. As shown in Table 6, $\mathrm{PC}_{1}$ is committed, which explains $59.9 \%$ of the aesthetic value. $\mathrm{PC}_{2}$ is secondly committed, as the next best thing, to account for this dependent variable, and then the ability of explanation is increased up to $80.1 \%$. It is therefore possible to say that the aesthetic value is positively affected by $\mathrm{PC}_{1}$ and $\mathrm{PC}_{2}$. $\mathrm{By} \mathrm{PC}_{3}$ and $\mathrm{PC}_{4}$, it is not able to clearly say how much the effect has on aesthetic values due to the fact that their significances are low. In view of the above, $\mathrm{PC}_{1}$ and $\mathrm{PC}_{2}$ are chosen as the predictors (in terms of $\mathrm{LAV}$ ), and the regression model of the comprehensive index score and LAV mean score is expressed in the following equation:

$$
L A V=0.09+0.493 P_{1}+0.424 P_{2}
$$

Note: the complete formula of $\mathrm{PC}_{1}$ and $\mathrm{PC}_{2}$ is shown in 3.3.

Table 6. Interactions between landscape aesthetic values and $\mathrm{PC}_{S}$ 


\begin{tabular}{|llllll|}
\hline Model & $\begin{array}{l}\text { Un-standardized } \\
\text { Coefficients }\end{array}$ & $\begin{array}{l}\text { Standardized } \\
\text { Coefficients }\end{array}$ & & & \\
\cline { 1 - 4 } $\mathrm{B}$ & Std. Error & Beta & & & \\
\hline 1 & (Constant) & .009 & .083 & .107 & .915 \\
\hline $\mathrm{PC}_{1}$ & .493 & .084 & .599 & 5.895 & .000 \\
\hline 2 & (Constant) & .009 & .064 & .139 & .890 \\
\hline $\mathrm{PC}_{1}$ & .493 & .064 & .599 & 7.646 & .000 \\
\hline $\mathrm{PC}_{2}$ & .424 & .064 & .801 & 6.579 & .000 \\
\hline
\end{tabular}

\section{Discussion}

$\mathrm{PC}_{1}$ and $\mathrm{PC}_{2}$ are proved to be the most important factors in the determination of landscape aesthetic of forests. Though $\mathrm{PC}_{3}$ has no significant relationship with the landscape aesthetic values, it does not mean that $\mathrm{PC}_{3}$ is pointless. Wildness, naturalness and localism are also of special significance due to their reflection of the characteristics of forest landscape, which keep citizens away from urbanization, and make the sites ideal for people to return to nature and relax (Mayrhofer et al., 2015; Mulller et al., 2015; Subiza-Perez et al., 2019). $\mathrm{PC}_{3}$ is able to bring these functions to the forests with strong local and nature flavor, as well as more peaceful atmosphere (Hofmann et al., 2012; Lupp et al., 2013). According to the PCA results, SS should be extracted as the fourth principal component alone. Nevertheless, ANOVA and regression analysis show no significant correlation between $\mathrm{PC}_{4}$ and $\mathrm{LAV}$. The main reason is that the difference of SS among the 64 samples is rather small.

4.1 Guidance for the planning and management of forest landscapes in Nanjing urban forest parks According to the current research, and taking a reference to the measures for the administration of national forest parks implemented since 2011 in China, three suggestions for forest landscape construction and protection are put forward as follows.

(1) To improve the vegetation element richness. A multi-hierarchical structure forest landscape, composed of trees, shrubs, flowers, and grass, embeds large amount of aesthetic values. The combination mode, i.e., tall trees as the background layer of forests, small trees and large shrubs as the medium layer of forests, and low shrubs and lawns as the understory layer of forests, is advised to be utilized, thereby changing the single-hierarchical structure characterized by pure trees and grasses.

(2) To enrich the types of forest colors. The existing monotonous color of some forests can be adjusted through plating color-leaf trees. Therefore, color-leaf trees should be given priority to be planted, such as Acer buergerianum, Acer palmatum, and Ginkgo biloba, thus improving the forests' beauty in autumn. Besides, it is feasible to plant flowering plants, and the plants which bear fruit. However, please pay 
attention not to build an area of flowering plants with lots of artificial traces in forests, which tends to be identical with the landscape of an urban park.

(3) To create the magnificent feel and plant localism vegetation. Ancient trees, famous trees and tall trees should be protected, which should be taken with a priority to maintain the magnificent feel of the forest. The exotic vegetation inevitably evaporates the local and pristine natural atmosphere in forests, therefore, it is recommended that localism vegetation should be planted in priority in Nanjing Urban Forest Parks, such as Sapium sebiferum, Sophora japonica and Magnolia denudata.

\subsection{Innovation and Limitations of the Study}

This study introduced the aesthetic evaluation for forest landscape into Nanjing Urban Forest Parks. Although the accuracy of the evaluation may depend on the regional characteristics, the aesthetic evaluation results derived by SD or PCA and the data analysis present reasonable method for forest landscape evaluations to other areas in southeastern China with similar environment. Another thing we need to pay attention to is that the guidance of forest landscape management should be implemented strictly to build up scenic viewing spots in urban forest parks.

The major limitation and the matters needing attention for future study can be summarized as follows. Firstly, it is worth to perform this evaluation experiment again by showing a sample consisted of each forest landscape which involves four seasons to the respondent (Song X. H. et al., 2018; Fernandes et al., 2019). Secondly, due to the diversity of evaluation criteria, as well as the complexity of forests, this research still shows its limitations in terms of the evaluation criteria. In this paper, two attributes related to visual sense and psychological perception are considered to evaluate the aesthetic value of the forest landscape. However, it is believed that more environmental data should be taken into accounts, particularly in the investigation of large-scale forest parks, such as the water body that affects the visual effect of waterfront forest landscape. In the future, the consideration of more criteria is expected to generate more reasonable evaluation results of forest landscape quality.

\section{Conclusions}

For the four urban forest parks in Nanjing, the elements affecting aesthetic values of the forest landscape among the criteria of visual sense are mainly VER, CC, VD, VP, CR, CL, and AMT. On the other hand, among the criteria of psychological perception, HA, SS, SB, SF present important elements affecting aesthetic values. Four comprehensive indexes, based on the 15 criteria affecting the aesthetic of landscape forest, are obtained by PCA method, that is, the vegetation element diversity $\left(\mathrm{PC}_{1}\right)$, the magnificent feel $\left(\mathrm{PC}_{2}\right)$, the nature-pastoral feel $\left(\mathrm{PC}_{3}\right)$ and the sense of space $\left(\mathrm{PC}_{4}\right)$. All forest landscapes in four urban forest parks are classified into four clusters. After synthesizing the value distribution, and performing multiple comparisons of $\mathrm{PCs}$, it is found that $\mathrm{PC}_{3}$ and $\mathrm{PC}_{4}$ have less influence on aesthetic values than $\mathrm{PC}_{1}$ and $\mathrm{PC}_{2}$ do. 
The utilization of SD and PCA methods to evaluate the aesthetic of forest landscape can make a useful support system for forest protection and management to satisfy the aesthetic needs of citizens. Moreover, diversified evaluation ways and means, multidimensional perceptual (visual sense and psychological perception) combination and multi-perspective approaches should be integrated to obtain all-round forest landscape information, thereby achieving better and objective evaluation of the effect. The results of this study will contribute to the preservation of aesthetic forest landscapes, maintenance of their sustainability, and integration of these conclusions into the development strategies of urban forest parks.

\section{Declarations}

Acknowledgments We are very grateful to Nanjing Garden and Forestry Bureau for their help in data collection. We also thank students from Nanjing Forestry University for participating in the questionnaire in this study.

Author Contributions Y.Y. conceived the idea and research design of this paper; Y.Y. performed data analysis; X.T. acquired the data; Y.Y. wrote the paper.

Funding information This research was funded by the National Natural Science Foundation of China (No. 31270746) and the scientific research innovation program for graduate students in Jiangsu Province (SJKY19_0870).

\section{Declarations}

Ethics approval and consent to participate Not applicable.

Conflict of interest The authors declare no competing interests

\section{References}

Campos, A., Oliveira, R.C. (2016). Cluster analysis applied to the evaluation of urban landscape quality. Sustainable City Xi, 204, 93-103.

Cervinka, R., Roderer, K., Hammerle, I. (2014). Evaluation of hospital gardens and implications for design: Benefits from environmental psychology for architecture and landscape planning. Journal of Architectural and Planning Research, 31(1), 43-56.

Daniel, T.C. (2001). Whither scenic beauty? Visual landscape quality assessment in the 21 st century. Landscape and Urban Planning, 54(1-4), 267-281.

Ertan Düzgüneş, Öner Demirel. (2015). Evaluation of rural areas in terms of landscape quality: Salacik Village (Trabzon/Turkey) example. Environmental Monitoring and Assessment, 187(6), 1-9.

Fernandes, A.C.P., Fernandes, L.F.S., Cortes, R.M.V., Pacheco, F.A.L. (2019). The role of landscape configuration, season, and distance from contaminant sources on the degradation of stream water quality 
in urban catchments. Water, 11(10), 1-19.

Garman, S.L. (2004). Design and evaluation of a forest landscape change model for western oreagon. Ecological Modelling, 175 (4), 319-337.

Ha, S.C., Yang, Z.P. (2019). Evaluation for landscape aesthetic value of the natural world heritage site. Environmental Monitoring and Assessment, 191(8), 1-20.

Hessburg, P.F., Reynolds, K.M., Salter, R.B., Dickinson, J.D., Gaines, W.L., Harrod, R.J. (2013). Landscape evaluation for restoration planning on the okanogan-wenatchee national forest, USA. Sustainability, 5 (3), 805-840.

Hofmann, M., Westermann, J.R., Kowarik, I., van der Meer, E. (2012). Perceptions of parks and urban derelict land by landscape planners and residents. Urban Forestry \& Urban Greening, 11 (3), 303-312.

Ikei, H., Song, C.R., Miyazaki, Y. (2017). Physiological effects of wood on humans: A review. Journal of Wood Science, 63 (1), 1-23.

Jeon, J.Y., Hwang, I.H., Hong, J.Y. (2014). Soundscape evaluation in a catholic cathedral and buddhist temple precincts through social surveys and soundwalks. Journal of the Acoustical Society of America, 135 (4), 1863-1874.

Jiang, M.Y., Hassan, A., Chen, Q.B., Liu, Y.G. (2019). Effects of different landscape visual stimuli on psychophysiological responses in Chinese students. Indoor and Built Environment,29 (7), 1006-1016.

Kim, N.H., Kang, H.H. (2009). The aesthetic evaluation of coastal landscape. Ksce Journal of Civil Engineering, 13 (2), 65-74.

Kisi, N.A. (2019). Strategic approach to sustainable tourism development using the a'wot hybrid method: A case study of zonguldak, turkey. Sustainability,11 (4), 1-19.

Kotlarz, J., Kubiak, K., Kacprzak, M., Czapski, P. (2016). Estimation of tree species diversity of forest stands based on their spectral reflectance. Sylwan, 160 (12), 1036-1045.

Kuper, R. (2017). Evaluations of landscape preference, complexity, and coherence for designed digital landscape models. Landscape and Urban Planning, 157, 407-421.

Kurdoglu, O., Kurdoglu, B.C. (2016). Semantic evaluation of waterfalls as tourism destinations. Journal of Environmental Protection and Ecology, 17 (2), 781-788.

Lim, E.M., Honjo, T., Umeki, K. (2006). The validity of vrml images as a stimulus for landscape assessment. Landscape and Urban Planning, 77 (1-2), 80-93.

Liu, X.L., Yang, Z.P., Di, F., Chen, X.G. (2009). Evaluation on tourism ecological security in nature heritage sites -case of kanas nature reserve of Xinjiang, China. Chinese Geographical Science.19(3), 265-273. 
Liu, Y.P., Hu, M.J., Zhao, B. (2019). Audio-visual interactive evaluation of the forest landscape based on eye-tracking experiments. Urban Forestry \& Urban Greening, 46, 1-11.

Lupp, G., Konold, W., Bastian, O. (2013). Landscape management and landscape changes towards more naturalness and wilderness: Effects on scenic qualities-the case of the muritz national park in germany. Journal for Nature Conservation, 21 (1), 10-21.

Malik, M.A.S., Shah, S.A., Zaman, K. (2016). Tourism in austria: Biodiversity, environmental sustainability, and growth issues. Environmental Science and Pollution Research, 23(23), 24178-24194.

Mayrhofer, S., Kirchmeir, H., Weigand, E., Mayrhofer, E. (2015). Assessment of forest wilderness in kalkalpen national park. Eco Mont-Journal on Protected Mountain Areas Research, 7(2), 30-40.

Mezosi, G., Csorba, P., Bata, T., Blanka, V., Ladanyi, Z. (2016). Similarity assessment of natural landscapes based on taxonomic distance. Applied Ecology and Environmental Research, 14, 679-693.

Micallef, A., Williams, A.T., Gallego-Fernandez, J.B. (2011). Bathing area quality and landscape evaluation on the mediterranean coast of andalucia, spain. Journal of Coastal Research, 61, 87-95.

Mulller, A., Bocher, P.K., Svenning, J.C. (2015). Where are the wilder parts of anthropogenic landscapes? A mapping case study for denmark. Landscape and Urban Planning, 144, 90-102.

Munoz-Pedreros, A., Larrain, A. (2002). The impact of forestry, agriculture, and cattle grazing activities on the quality of landscape in a transect of southern chile. Revista Chilena De Historia Natural. 75 (8), 673689.

Nam, H. K., H, H. K. (2009). The aesthetic evaluation of coastal landscape. KSCE Journal of Civil Engineering, 13(2), 65-74.

Park, B.J., Furuya, K., Kasetani, T., Takayama, N., Kagawa, T., Miyazaki, Y. (2011). Relationship between psychological responses and physical environments in forest settings. Landscape and Urban Planning, 102(1), 24-32.

Petrova, E.G., Mironov, Y.V., Aoki, Y., Matsushima, H., Ebine, S., Furuya, K., Petrova, A., Takayama, N., Ueda, $H$. (2015). Comparing the visual perception and aesthetic evaluation of natural landscapes in russia and japan: Cultural and environmental factors. Progress in Earth and Planetary Science. 2(1), 1-12.

Qi, T., Zhang, G.Q., Wang, Y.J., Liu, C.N., Li, X.Y. (2017). Research on landscape quality of country parks in Beijing as based on visual and audible senses. Urban Forestry \& Urban Greening, 26, 124-138.

Rizio, D., Gios, G. (2014). A sustainable tourism paradigm: opportunities and limits for forest landscape planning. Sustainability, 6(4), 2379-2391.

Romero, A.G., Santos-Olmo, M.A.S.D., Mendez-Mendez, A., Chavez, E.S. (2019). Design and application of landscape quality indicators for the evaluation of tourist attractions in rural areas. Revista De Geografia 
Saleh, M.A.E. (2001). Environmental cognition in the vernacular landscape: Assessing the aesthetic quality of al-alkhalaf village, southwestern saudi arabia. Building and Environment, 36(8), 965-979.

Santosa, H., Ernawati, J., Wulandari, L.D. (2018). Visual quality evaluation of urban commercial streetscape for the development of landscape visual planning system in provincial street corridors in malang, indonesia. Friendly City 4 from Research to Implementation for Better Sustainability, 126, 202212.

Schirpke, U., Tasser, E., Tappeiner, U. (2013). Predicting scenic beauty of mountain regions. Landscape and Urban Planning, 111, 1-12.

Silva, R.A., Pereira, J.A.A., de Barros, D.A., Borges, L.A.C., Teixeira, M.D., Acerbi, F.W. (2015). Forest cover evaluation in the atlantic forest landscape of the ouro preto region-mg, in the year 2010. Cerne, 21(2), 301309.

Ha S.C., Yang, Z.P. (2019). Evaluation for landscape aesthetic value of the Natural World Heritage Site. Environmental Monitoring and Assessment, 191(8), 1-20.

Song, C., Ikei, H., Igarashi, M., Miwa, M., Takagaki, M., Miyazaki, Y. (2014). Physiological and psychological responses of young males during spring-time walks in urban parks. Journal of Physiological Anthropology, 33(8),1-7.

Song, C., Ikei, H., Kagawa, T., Miyazaki, Y. (2019). Effects of walking in a forest on young women. International Journal of Environmental Research and Public Health,16(2), 1-12.

Song, X.H., Lv, X.B., Yu, D.M., Wu, Q.Q. (2018). Spatial-temporal change analysis of plant soundscapes and their design methods. Urban Forestry \& Urban Greening, 29, 96-105.

Subiza-Perez, M., Hauru, K., Korpela, K., Haapala, A., Lehvavirta, S. (2019). Perceived environmental aesthetic qualities scale (peaqs) - a self-report tool for the evaluation of green-blue spaces. Urban Forestry \& Urban Greening, 43(7), 126-183.

Takayama, N., Fujiwara, A., Saito, H., Horiuchi, M. (2017). Management effectiveness of a secondary coniferous forest for landscape appreciation and psychological restoration. International Journal of Environmental Research and Public Health, 14(7), 800-815.

Tarakci-Eren, E., Duzenli, T. (2017). Determination of the visual preference levels and perceptual differences in the appearance of certain taxa in different seasons. Fresenius Environmental Bulletin, 26(12A), 8304-8315.

Torres-Sibille, A.D., Cloquell-Ballester, V.A., Cloquell-Ballester, V.A., Ramirez, M.A.A. (2009). Aesthetic impact assessment of solar power plants: An objective and a subjective approach. Renewable \& Sustainable 
Energy Reviews, 13(5), 986-999.

Wan, L., Fan, X.H. (2018). Water quality of inflows to the everglades national park over three decades (1985-2014) analyzed by multivariate statistical methods. International Journal of Environmental Research and Public Health, 15(9), 1882-1991.

Wang, Q., Xul, J.C., Li, G.M., He, W.Y. (2011). Assessment of urban landscape water using multivariate statistical techniques. Fresenius Environmental Bulletin, 20(1), 182-189.

Yang, X.J. (2014). Structural quality in waterfront green space of shaoyang city by scenic beauty evaluation. Asian Journal of Chemistry, 26(17), 5644-5648.

Yazici, K. (2018). Evaluation of visual landscape quality in the wetlands north of sivas (turkey). Applied Ecology and Environmental Research, 16(4), 4183-4197.

Zhang, C.X., Yang, Z.P. (2016). Evaluation of urban agricultural landscape based on analytic hierarchy process. Agro Food Industry Hi-Tech. 27, 42-46.

Zhang, T., Deng, S.Q., Ma, Q.Q., Sasaki, K. (2015). Evaluations of landscape locations along trails based on walking experiences and distances traveled in the akasawa forest therapy base, central japan. Forests, 6(8), 2853-2878.

Zhang, Z., Qie, G.F., Wang, C., Jiang, S.S., Li, X., Li, M.X. (2017). Relationship between forest color characteristics and scenic beauty: case study analyzing pictures of mountainous forests at sloped positions in Jiuzhai Valley, China. Forests, 8(63), 1-19.

Zhang, T., Zhang, WK., Meng, H.,; Zhang, Z.(2019) . Analyzing visitors' preferences and evaluation of satisfaction based on different attributes, with forest trails in the Akasawa National Recreational Forest, Central Japan. Forests, 10(5), 1-19.

\section{Figures}




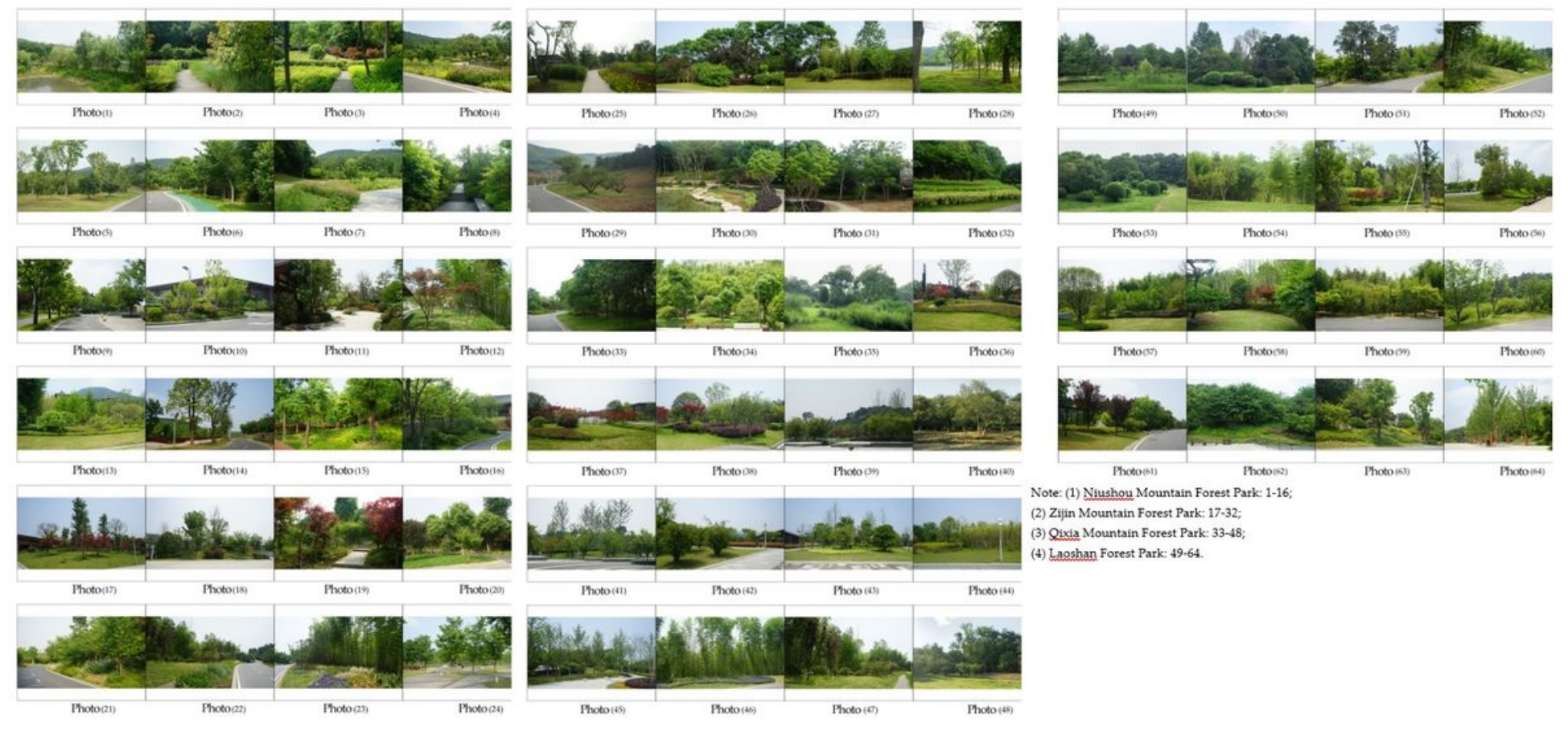

Figure 1

64 photos of forest landscapes in four urban forest parks

\section{Supplementary Files}

This is a list of supplementary files associated with this preprint. Click to download.

- appendix.docx 